\title{
Firsat Sitelerinden Tekrar Satın Alma Kararını Etkileyen Faktörlerin Araştırılması
}

\author{
Çiğdem ALTIN GÜMÜȘSOY, Ali Can YETEREL \\ İstanbul Teknik Üniversitesi \\ altinci@itu.edu.tr, acyeterel@gmail.com \\ (Geliş/Received: 27.04.2016; Kabul/Accepted: 15.07.2016) \\ DOI: $10.17671 /$ btd. 99722
}

\begin{abstract}
$\ddot{O}_{z}$ et - Fırsat siteleri, işletmelerin ürün ve hizmetlerini, müşterilerine indirimli kuponlar halinde sunmalarını sağlayan sanal ortamlar olarak tanımlanabilir. Fırsat sitelerinin çeşitliliği ve sayısının artması ile birlikte müşteriler artık aynı ürün/hizmeti alternatif bir web sitesinden edinebilmektedirler. Oysaki firmaların varlıklarını sürdürmelerinde var olan müşteriyi korumak yeni bir müşteri edinmeye göre daha az maliyetlidir. Bu çalışmanın amacı, firsat sitelerinden alışveriş yapan müşterilerin ilgili web sitesinden tekrar alışveriş yapmaya karar vermelerinde etkili olan faktörlerin araştırılmasıdır. Bunun için, memnuniyet, algılanan fayda, algılanan kullanım kolaylığı, kişisel normlar, algılanan saygınlık ve güven faktörlerini içeren bir araştırma modeli oluşturulmuştur. Araştırma modeli, firsat sitelerinin aktif kullanıcılarından toplanan anketler kullanılarak test edilmiştir. Analiz için yapısal eşitlik modellemesi kullanılmıştır. Sonuçlara göre güven ve memnuniyet faktörleri tekrar satın alma kararını etkilemektedir. Memnuniyet ise güven, algılanan fayda ve algılanan kullanım kalaylığı tarafından açıklanmaktadır. Kişisel normların, algılanan fayda üzerinde anlamlı bir etkisi bulunmasına rağmen tekrar satın alma niyeti üzerindeki etkisi anlamlı bulunmamıştır. Çalışmanın sonunda, çalışmanın sonuçları ve ileride yapılabilecek çalışmalar üzerinde durulmuştur.
\end{abstract}

Anahtar Kelimeler - Fırsat sitesi; tekrar satın alma niyeti; güven; memnuniyet; algılanan fayda, algılanan kullanım kolaylığı; algılanan saygınlık; kişisel normlar

\section{Examining the Factors Affecting the Decision to Repurchase Intention from Group-Buying Websites}

\begin{abstract}
Group-buying websites are the virtual environments that the firms can sell products or services to their customers using coupons that offer price discounts. For the continuity of the firms, maintaining current customers is more important and cost effective than finding new customers. A research model is developed to identify the determinants of reuse intention of group-buying websites. To do this, the research model is constructed including the variables-satisfaction, perceived usefulness, perceived ease of use, subjective norms, perceived reputation and trust. The measurement and structural model are tested using the data, collected from the actual users of group-buying websites. In the analysis, LISREL 8.54 software is used. According to the results, trust and satisfaction are the predictors of repurchase intention. Satisfaction is explained with the variables trust, perceived usefulness and perceived ease of use. Although subjective norm has a significant effect on perceived usefulness its effect is found to be insignificant on repurchase intention. At the conclusion, the results and possible future studies are discussed.
\end{abstract}

Keywords - Group buying website; repurchase intention; trust; satisfaction; perceived usefulness; perceived ease of use; perceived reputation; subjective norms

\section{GİRIŞ (INTRODUCTION)}

Firsat siteleri, işletmelerin ürün ve hizmetlerini, müşterilerine indirimli kuponlar halinde sunmalarını sağlayan sanal ortamlar olarak tanımlanabilir. Firmalar, müşterileri için belirledikleri firsatları belli bir zaman diliminde firsat siteleri vasitasıyla sunabilmektedir. Böylece müşterilerine ürün/hizmeti sunmadan önce müşterilerinden ürün/hizmet ödemesini alabilmekte ve günlük farklı alternatif firsatları ile müşterilerinin ilgisini canlı tutulabilmektedirler [1]. Edelman ve diğ. [2]'ne göre firsat siteleri, sunulan indirimli kuponlarla firmalara fiyatta farklılaşma sağlamakla birlikte pazarlama açısından yeni müşteriler çekmek için bir pazarlama aracı olarak kullanılabilir. Ayrıca potansiyel müşteriler sadece fırsat sitesi vasıtası ile değil diğger alternatif sosyal paylaşım kanallarıyla da sunulan firsatı paylaşarak potansiyel müşteriye erişim daha geniş bir alanda sağlanabilmektedir [1]. Müşteri açısından ise fiyat avantajının yanında aynı fiyatta daha iyi, kaliteli ürün alabilme, ürünü rahatlıkla edinebilme, daha ucuza aynı 
ürünü aldığı için kendini iyi hissetme, moral yüksekliği ve sürecin eğlenceli olarak algılanması sıralanabilir [3].

Frrsat sitesi kavramı 2008 yılında groupon.com ile bilinirliği artmış bir kavramdır. Firmalar, müşterilerine $\% 50$ veya daha yüksek oranda indirimler sunarak diğer rakiplerine göre fiyat avantajı yakalamışlar ve daha önce müşteri portföyünde olmayan müşterileri de çekebilmişlerdir. Fakat bu tür hizmet veren firsat sitelerinin sayısının artmasıyla birlikte firmaların pazardaki payı azalmış ve faaliyete başlayan birçok firsat sitesi küçülmüş veya kapanmak durumunda kalmıştır. Örneğin Groupon'un 2010 yılında halka arz değeri 12,7 milyar dolar iken 2013 yılına gelindiğinde değeri onda birine düşmüştür [2]. Firmanın 2014 ve 2015 yıllarının son çeyreklerine ait finansal verileri incelendiğinde Amerika dışındaki ülkelerde 2014 yılında 60 milyon dolar olan gelir 2015 yılında 46 milyon dolara gerilemiştir [4]. Ayrıca sayıları hızla artan fırsat siteleriyle müşteriler aynı ürünü sunan bir firsat sitesinden diğerine kolaylikla geçebilmektedirler [5]. Dolayısıyla firsat siteleri için, yoğun rekabet ortamında müşterilerinin firmaya bağlılıkları, yani aynı fırsat sitesinden tekrarlı alışveriş yapma, firma devamlılığı ve başarısı için önemlidir.

$\mathrm{Bu}$ çalışmanın amacı fırsat sitesinden faydalanan bir müşterinin firsat sitesini tekrar kullanma kararında etkili olan faktörlerin ortaya çıkarılmasıdır. Özellikle memnuniyet, algilanan fayda, algılanan kullanım kolaylığı, güven, kişisel normlar ve firmanın algılanan saygınlığının tekrar satın alma niyetine etkisi araştırılacaktır. Böylece fırsat sitesi sağlayıcıları için, var olan müşterilerin devamlılığının sağlanmasında etkili faktörlerin ortaya çıkarılması hedeflenmektedir.

Spesifik olarak bu çalışmada aşağıdaki sorulara cevap aranacaktır: (1) Güven, kişisel normlar ve memnuniyet faktörlerinin, firsat sitelerinden tekrar satın alma niyetine etkileri var midır? (2) Algılanan kullanım kolaylığı, algılanan fayda ve güven faktörünün memnuniyet üzerindeki etkisi nedir? (3) Algılanan saygınlık faktörünün güven ve algılanan fayda üzerindeki etkisi nasıldır? Çalışmanın bir sonraki bölümünde firsat siteleriyle ilgili literatürde yapılan çalışmalardan bahsedilecektir. Üçüncü bölümde tekrar satın alma niyetini etkileyen faktörleri ortaya koyan araştırma modeli anlatılacaktır. Sonraki bölümde kullanılan yöntem, analiz sonuçları ve en son bölümde de sonuçlar tartışılarak ileride yapılabilecek çalışmalar hakkında bilgi verilecektir.

\section{LITERATÜR TARAMASI (LITERATURE REVIEW)}

Literatür incelendiğinde firsat sitelerinin tekrar kullanım niyetine etki eden faktörleri araştıran çalışmalar mevcuttur [6, 1, 7, 8, 5]. Zhang ve diğ. [6], çalışmalarında Beklenti-Onay Teori'sini temel alan modellerine algilanan fiyat avantajı, algilanan saygınlık, algılanan web sitesi kalitesi ve sosyal baskı faktörlerini de ekleyerek tekrar kullanım niyetine etki eden faktörleri araştırmışlardır. Çalışma, Çin'de faaliyet gösteren firsat sitesini kullanan kişilere anket uygulanarak gerçekleştirilmiştir. Sonuçlara göre memnuniyet, algılanan saygınlık ve sosyal baskının tekrar kullanım niyetine pozitif etkileri bulunmaktadır. Sigala [1], firsat siteleri açısından müşteri davranışlarını dört aşamada incelemiştir: Müşterinin firsat sitesinden indirimli kuponla ilgili bilgi alması, incelemesi, müşterinin indirimli kuponu satın alması, müşterinin aldığı kuponu kullanması ve müşterinin kullandığ 1 kupondan aldığ1 memnuniyet durumuna göre daha sonra göstereceği davranışlar. $\mathrm{Bu}$ çalışmada, her bir safhada hangi faktörlerin önemli olduğu yönünde niteleyici bir çalışma gerçekleştirilmiştir. Shiau ve Luo [7], çalışmalarında satın alma sonucu oluşan memnuniyet ve satıcı-yaratıcılığının tekrar satın alma niyetine ve ayrıca güven ve saygınlığın memnuniyete etkilerini araştırmışlardır. Huang ve diğg. [8], DeLone\&McLean Bilişim Sistemleri Başarı Modeli'ni temel alarak bilgi kalitesi, hizmet kalitesi, sistem kalitesinin kullanıcının firsat sitesine olan sadakati ve tekrar satın alma niyetine etkilerini araştırmışlardır. Hsu ve diğ. [5], firsat sitelerinden tekrar satın almayı etkileyen faktörleri araştırırken web sitesinden memnuniyet, satıcıdan memnuniyet ve güven faktörlerinin etkilerini çalışmalarında ayrı ayrı incelemişlerdir.

Literatür araştırması göstermiştir ki tekrar satın alma kararını etkileyen en önemli faktörlerden biri memnuniyettir [5-7, 1]. Müşteriler memnun kaldıkları sistemi tekrar kullanmayı istemektedirler. Ayrıca müşterilerin çevrelerinden hissettikleri sosyal bask1 özellikle kendileri için önemli kişilerin sistemi kullanmaları ve müşterilere de bu yönlü telkinlerde bulunmaları tekrarlı kullanımı etkilemektedir [7]. Diğer taraftan sistemin, kullanıcıların gözünde faydalı olarak algılanması ve kullanımının kolaylığı da memnuniyeti etkilemektedir [9, 10]. Elektronik ticarette sisteme ve satıcıya güven olmadan sistemin kullanımı veya tekrarlı kullanımı beklenemez. Kullanıcılar güven problemiyle karşıllaştıklarında sistemden memnun kalmazlar ve sonucunda da sistemi kullanmayı bırakırlar [7]. Ayrıca firmanın kullanıcının gözündeki saygınlığı firmaya duyulan güveni arttırır ve sunulan sistemin daha faydalı olduğu yönündeki algıyı da olumlu yönde etkiler $[7,6,5$, 8].

Sonuç olarak oluşturulan araştırma modeli ile memnuniyet, güven ve kişisel normların tekrar kullanım niyeti üzerindeki etkileri; algılanan fayda, algılanan kullanım kolaylığı ve güven faktörlerinin memnuniyet üzerindeki etkileri; algılanan saygınlığın güven ve algılanan fayda üzerindeki etkileri araştırılacaktır.

\section{ARAŞTIRMA MODELİ (RESEARCH MODEL)}

Tekrar satın alma niyetini açıklamayı hedefleyen teorik model Şekil 1'dedir. 


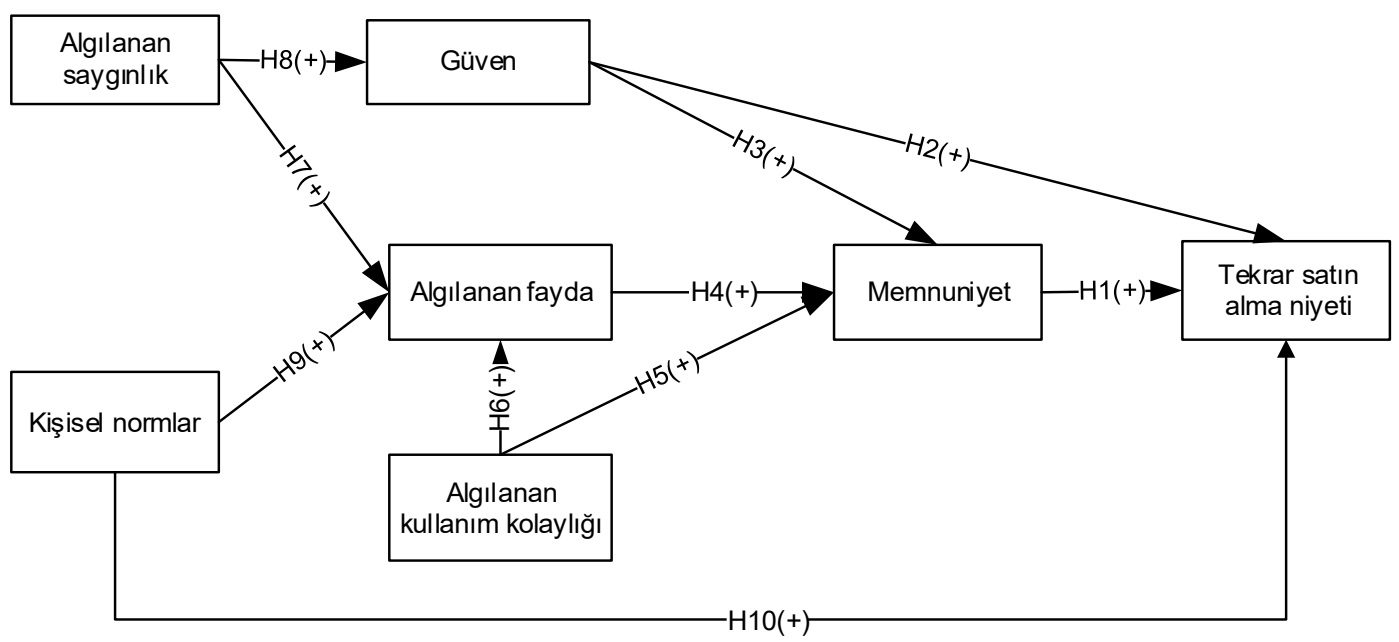

Şekil 1. Teorik model

\subsection{Tekrar satın alma niyeti}

Tekrar kullanım niyeti, uzunca bir süre bilişim teknolojilerini kullanmayı sürdürme kararı olarak düşünülebilir. Teknoloji Kabul Modeli, herhangi bir bilişim teknolojisinin kullanım niyetine ve gerçek kullanım niyetine etki eden faktörleri araştıran güvenilir bir modeldir. Teknoloji Kabul Modelinde, bilişim teknolojilerinin ilk kullanım niyeti ve gerçek kullanımına etki eden faktörler araştırılırken bilişim teknolojilerinin gelecekte kullanmayı sürdürme kararını etkileyen faktörleri açıklayan Beklenti-Onay Teorisi Bhattacherjee [11] tarafindan geliştirilmiştir. Bhattacherjee [11], çalışmasında tekrar kullanım niyetini bir süreç olarak tanımlamıştır. İlk aşamada potansiyel kullanıcının gözünde sistemle ilgili bir beklenti oluşur. İkinci aşamada, beklentilerine uyum gösteren sistemler kullanıcılar tarafindan kabul edilir ve kullanılmaya başlanır. Üçüncü aşamada sistemin belli bir süre kullanımından sonra kullanıcılar açısından sistem performansına yönelik ilk izlenimler oluşur. Kullanıcının beklentileri ile gerçekleşen performans arasındaki farka göre müşteride memnuniyet oluşabilir. Ayrıca sistemin kullanıcilar tarafindan faydalı olarak algilanması da memnuniyetle birlikte sistemin tekrarlı kullanımını etkiler [11].

\subsection{Memnuniyet}

Kullanıcı memnuniyeti, kullanıcıların sistem beklentileri ile tecrübeleri arasındaki fark ile ilişkilendirilebilir. Herhangi bir sistemi tekrar kullanmak isteyen kullanıcılar, sistemden memnun kaldıkları sürece sistemi kullanmayı sürdürürler [11] ve bu tür kullanıciların sistemi kullanmayı birakması beklenmez [12]. Beklenti-Onay Teorisi'nde açıklandığı üzere tekrar kullanım niyetini etkileyen faktörlerden biri memnuniyettir. Ayrıca birçok çalışmada farklı teknolojilerden memnuniyetin ilgili teknolojiyi tekrar kullanım niyeti üzerindeki olumlu etkisi gösterilmiştir: firsat sitesi [5], internet alışverişi [13], toplu e-alışveriş [6], e-öğrenme [14, 15], mobil ödeme sistemi [16]. Sonuç olarak, bu çalışmada aşağıdaki hipotez oluşturulmuştur:

H1: Memnuniyetin tekrar satın alma niyeti üzerinde pozitif etkisi vardır.

\subsection{Güven}

Kullanıcı için güven, hizmet sağlayıcının kullanıcı için önemli olabilecek aksiyonları yerine getirebilme yeteneğiyle ilişkilidir [17]. Güven, satıcının kendi çıkarları yanında müşterisinin çıkarlarını düşünme, kullanıcıya verilen taahhütleri yerine getirme, müşteriyi kandırmama ve satıcının müşterinin isteklerinin yerine getirebilme yetenek ve bilgisine sahip olma ile ilgili müşterinin beklentilerinin toplamıdır $[18,16]$. Özellikle eticarette alıcı-satıcı arasındaki ilişkide güven çok önemlidir [19]. Güven, potansiyel müşterilerin söz konusu internet sitesinde daha fazla vakit geçirmelerini, internet sitesinin sayfaları arasında dolaşmalarını, siteye katkıda bulunmalarını (yorum vb.) ve diğer insanlarla bağlantılı hale gelmelerini sağlar

Ayrıca e-ticarete karşı olumlu duyguların oluşmasını sağlar. Müşterinin satıcıya duyduğu güven ise müşteri memnuniyetini ve bağlılığını etkilemektedir [7]. Müşterilerin siteye duydukları güven ne kadar yüksekse siteden duydukları memnuniyet artmakta ve sonrasında güven duydukları siteyi kullanmak alışkanlık haline gelerek müşterilerin siteyi tekrarlı kullanmalarına neden olmaktadır [20]. Literatürdeki birçok çalışmada güven faktörünün memnuniyet $[7,21]$ ve tekrarlı satın alma niyeti [20] üzerindeki etkisi gösterilmiştir. Sonuç olarak, aşağıdaki hipotezler oluşturulmuştur:

H2: Güven arttıkça müşteriler aldıkları hizmeti tekrar satın almaya niyet ederler. 
H3: Güvenin memnuniyet üzerindeki etkisi anlamlıdır.

\subsection{Algilanan Fayda}

Algılanan fayda, kullanıcıların herhangi bir bilişim sistemini kullanmaları sonucu oluşan performanslarındaki artış beklentisini ifade eder. [22]. Davis ve diğ. [23] Teknoloji Kabul Modeli'nde kullanım niyetini en iyi açıklayan değişkenlerden birinin algılanan fayda olduğunu çalışmalarında ifade etmişlerdir. Bhattacherjee [11], Beklenti-Onay Teorisi'ni açıklarken algılanan fayda memnuniyeti arttırmakta ve memnuniyetle birlikte de bilişim sisteminin tekrar kullanım niyetini açıklamaktadır. Literatürde Beklenti-Onay Teorisi'ni kullanan çalışmalarda da algılanan faydanın memnuniyet üzerindeki etkisi gösterilmiştir [örn: 9]. Sonuç olarak aşağıdaki hipotez oluşturulmuştur:

H4: Algılanan fayda arttıkça müşterilerin memnuniyeti de artar.

\subsection{Algılanan kullanım kolaylığ}

Algılanan kullanım kolaylığı, kullanıcıların sistemi kullanırken karşılaştıkları kullanım zorluklarının kişisel derecesi olarak ifade edilebilir. Algılanan kullanım kolaylığı, kişinin sistemi kullanırken harcaması gereken çaba olarak da ifade edilebilir [22]. Müşteriler açısından sistemin kullanımı ne kadar kolaysa harcayacakları çaba ve zaman o kadar az olur ki bu durum da kullanıcılar açısından sistemin faydalı olduğu algısını arttırır. Algılanan kullanım kolaylığının algılanan fayda üzerindeki etkisi Teknoloji Kabul Modeli tabanlı birçok çalışmada gösterilmiştir [24]. Wang ve Chou [24], algılanan faydayı etkileyen faktörler olarak algılanan kullanım kolaylığı, kişisel normlar, ekonomik alışveriş eğilimi ve bilgi kalitesinin anlamlı etkileri olduğunu çalışmalarında göstermişlerdir. Ayrıca algılanan kullanım kolaylığı kullanılan sisteme karşı tavrı etkilediğinden ve memnuniyetin de bir tavır olduğu düşünüldüğünde algılanan kullanım kolaylığının memnuniyeti olumlu yönde etkilemesi beklenir [10]. Sonuç olarak bu çalışmada aşağıdaki hipotezler oluşturulmuştur:

H5: Sistemin kullanımı kolaylaştıkça müşterilerin memnuniyeti artar.

H6: Kullanım kolaylaştıkça müşteriler sistemi daha faydalı olarak algilarlar.

\subsection{Algilanan saygınlık}

Potansiyel müşteriler açısından algılanan saygınlık, firmanın dürüstlüğü ve müşterilerine karşı gösterdiği ilginin derecesi olarak algılanabilir [25]. Firmaların saygınlıklarını artırması büyük yatırımlarla, gayret ve tutarlı bir hizmetle sağlanabilir [6]. Bu algının eksikliği, daha internet üzerinden alışveriş yapmamış ya da söz konusu internet sitesinden herhangi bir alışveriş yapmamış kullanıcılar için güvensizlik yaratabilmektedir.

Sistem veya sistem sağlayıcının algılanan saygınlığı, müşterinin güven algısını yükseltir. Koufaris ve Hampton-Sosa [25], e-ticarette firmaya yönelik ilk güven duygusunun oluşmasında firmayla ilgili özelliklerden algılanan saygınlık ve ürünlerin özelleştirilebilmesinin önemli olduğunu ortaya çıkarmışlardır. Firmalar, kendilerine duyulan saygınlığı arttırmak için yatırımlar yaparlar. Müşterilerin de firsat sitesinin veya ilgili ürün/hizmet sağlayıcıların firmanın kazandığı saygınlığa zarar vermeyecekleri şekilde davranacaklarına yönelik alg1 firsat sitesine olan güvenin artmasını sağlar [5]. Ayrıca müşterilerinin gözünde saygınlığı yükseltilmiş bir e-ticaret sitesinin sunduğu ürün/hizmetin faydalı olması beklenir. Müşteri bakış açısıyla hizmet sağlayıcının kendileri için faydalı ürünler sunacağına yönelik müşteri algısını da olumlu etkiler [26]. Sonuç olarak algılanan saygınlık, müşterilerin sistemle etkileşimi sonucu oluşan güven duygusunu ve sistemin faydalı olduğu yönündeki algısını etkiler. $\mathrm{Bu}$ çalışmada, aşağıdaki hipotezler oluşturulmuştur:

H7: Algılanan saygınlığın algılanan fayda üzerinde anlamlı bir etkisi vardır.

H8: Algılanan saygınlık arttıkça güven artar.

\subsection{Kişisel normlar}

Kişisel norm, kullanıcıların kendileri için önemli kişilerin sistemle ilgili söylediklerini, telkinlerini içermektedir. [27]. Planlı Davranış Teorisi'ne göre herhangi bir davranışı gerçekleştirme niyeti kişisel normlar, algılanan davranışsal kontrol ve tutum tarafından açıklanabilir. Potansiyel kullanıcılar, kendileri için önemli kişilerin ilgili sistemi kullanması yönünde verdiğin öğüt neticesinde sistemi kullanabilir ve tekrarlı kullanmayı sürdürebilir [28]. Aynı hizmeti veren farklı firsat siteleri arasından seçim yapmak gerektiğinde sizin için önemli kişilerin söyledikleri önemli olabilir. Veya sizin için önemli biri firsat sitesinden aldığı bir ürün/hizmeti size de önerdiğinde sistemi kullanmaya karar verebilirsiniz. Dolayısıyla sistemin ilk kullanımında veya daha önce kullanmış olsanız bile sizin için önemli birinin önerisiyle firsat sitesini tekrar kullanması beklenebilir. Literatürdeki çalışmalarda kişisel normların algılanan fayda [24] ve tekrar satın alma niyeti [29] üzerindeki etkileri gösterilmiştir. Chen ve diğ. [29], çalışmalarında sosyal faktörlerden kişisel normlar, imaj, kritik ağırlık ve e-sözlü ifadelerin Web 2.0'dan memnuniyete ve tekrar kullanım kararına etkilerini araştırmışlardır. Sonuçlara göre kişisel normların tekrar kullanım niyeti ve memnuniyet üzerinde anlamlı pozitif bir etkisi vardır. Bu kapsamda aşağıdaki hipotezler oluşturulmuştur:

H9: Kişisel normların algılanan fayda üzerinde pozitif anlamlı bir etkisi vardır. 
H10: Kişisel normların tekrar satın alma niyetine anlamlı bir etkisi bulunmaktadır.

\section{YÖNTEM (METHODOLGY)}

$\mathrm{Bu}$ çalışmada anket metodolojisi kullanılmıştır. Anketin uygulandığ 1 hedef kitle Groupon.com firsat sitesinin Türkiye'de faaliyet gösteren firsat sitesinden, son altı ay içerisinde alışveriş gerçekleştiren müşterilerdir. Anketin ilk bölümünde anketi cevap verenleri tanımaya yönelik sorular bulunmaktadır. Bu sorular, cinsiyet, yaş, eğitim düzeyi, internet tecrübesi ve son altı ayda gerçekleştirilen alışveriş sayısına yönelik sorulardır.

İkinci bölümde kullanıcılara araştırma modelinde yer alan örtük değişkenleri tanımlayan gözlenen değişkenlerle ilgili sorular sorulmuştur. Anket soruları araştırma modelinde yer alan değişkenleri açıklamaya yönelik olarak literatür taraması yapılarak oluşturulmuştur [30-33, 9, 20, 25]. Anket katılanlar 7'li Likert ölçeğinde verilen cümlelere katılım derecelerini belirtmișlerdir. Skala "Kesinlikle katılmiyorum" ile "Kesinlikle katılıyorum" arasında ölçeklendirilmiştir. Ankette var olan gözlenen değişkenler ve referansları Tablo 2'de verilmiştir.

Soruların anlaşılırlığının tespiti için pilot çalışması uygulanmıştır. Pilot çalışması, çalışmadan sorumlu kişi tarafından yüz yüze anket uygulanarak gerçekleştirilmiştir. Pilot çalışmaya 10 kişi katılmıştır ve bu kişilerin değerlendirmeleri örnekleme dahil edilmemiştir. Anlaşılmayan sorular ve gelen yorumlar doğrultusunda anket sorularında düzeltmeler yapılarak anket formu nihai haline ulaşmıştır. Nihai anket sistem kullanıcılarına sosyal medya aracılığıyla ve yüz yüze görüşmelerle ulaştırılmıştır. Toplanılacak anket sayısının belirlenmesinde Hair ve diğ. [34] tarafindan önerilen yöntem kullanılmıştır. Hair ve diğ. (1988)'e göre örneklem sayısı anketi oluşturan bağımsız değişkenlerin en az 5 katı olmalıdır. Hazırlanan ankette 7 örtük değişkenin ölçümlenmesinde kullanılan toplam 29 bağımsız değişken olduğundan örneklem sayısı minimum 145 olmalıdır ve bunun üzerinde toplanan anket, çalışmanın genelleştirmesini sağlayacaktır. Yapılan çalışmada toplam 216 kullanıcıya ulaşılmıştır. Toplanan anketlere verilen cevapların bazılarının aynı veya büyük bir kısmının boş bırakılması ve/veya ankete katılanlar tarafından boş bırakılması gereken soruya cevap verenlerin anketleri dikkate alınmamıştır. Sonuç olarak bu anketler çıkarıldığında çalışmada analiz için 204 anket değerlendirilmeye alınmıştır.

Tablo 1, firsat sitesi kullanıcılarının kişisel özelliklerini özetlemektedir. Ankete cevap verenlerin \%47'si erkek, \%53'ü ise kadındır. Yaş grupları bazında baktığımızda ise anket katılımcılarının büyük bir oranı (\%72'si) 20-24 yaş arasındadır. Katılımcıların \%35'i üniversite mezunudur. Son altı ayda gerçekleştirilen alışveriş sayısında, ankete katılanların \%70'i bir veya iki defa ilgili firsat sitesinden alışveriş yaptıklarını belirtmişlerdir.
Tablo 1. Ankete katılan kullanıcıların kişisel özellikleri

\begin{tabular}{|c|c|c|}
\hline Cinsiyet (\%) & $\begin{array}{l}\text { Erkek } \\
\text { Kadın }\end{array}$ & $\begin{array}{l}47 \\
53\end{array}$ \\
\hline Yaş (\%) & $\begin{array}{l}20 \text { yaşından küçük } \\
20-24 \text { yaş aralığında } \\
25-29 \text { yaş aralığında } \\
30 \text { yaşından büyük }\end{array}$ & $\begin{array}{l}3 \\
72 \\
18 \\
7\end{array}$ \\
\hline Eğitim düzeyi (\%) & $\begin{array}{l}\text { Lise mezunu } \\
\text { Üniversite öğrencisi } \\
\text { Üniversite mezunu }\end{array}$ & $\begin{array}{l}3 \\
62 \\
35\end{array}$ \\
\hline İnternet tecrübesi (\%) & $\begin{array}{l}<5 \text { yillık tecrübe } \\
5-6 \text { y1llık tecrübe } \\
7-8 \text { y1llık tecrübe } \\
>9 \text { yillık tecrübe }\end{array}$ & $\begin{array}{l}4 \\
16 \\
26 \\
54\end{array}$ \\
\hline $\begin{array}{l}\text { Son } 6 \text { ayda firsat } \\
\text { sitelerinden } \\
\text { gerçekleştirilen alışveriş } \\
(\%)\end{array}$ & $\begin{array}{l}1-2 \mathrm{kez} \\
3-5 \mathrm{kez} \\
6-11 \mathrm{kez} \\
>11 \mathrm{kez}\end{array}$ & $\begin{array}{l}70 \\
24 \\
4 \\
2\end{array}$ \\
\hline
\end{tabular}


Tablo 2. Örtük değişkenler, referans çalışmalar ve gözlenen değişkenler

\begin{tabular}{|c|c|c|}
\hline $\begin{array}{l}\text { Örtük değişken } \\
\text { (Referans) }\end{array}$ & & Gözlenen değişkenler \\
\hline $\begin{array}{l}\text { Tekrar satın alma } \\
\text { niyeti [30] }\end{array}$ & $\begin{array}{l}\text { TK1 } \\
\text { TK2 } \\
\text { TK3 }\end{array}$ & $\begin{array}{l}\text {...com'u tekrar kullanmayı düşünüyorum. } \\
\text {...com'u gelecekte düzenli olarak kullanmayı planlıyorum. } \\
\text {...com’u gelecekte de kullanmaya devam edeceğim. }\end{array}$ \\
\hline Memnuniyet [31] & $\begin{array}{l}\text { M1 } \\
\text { M2 } \\
\text { M3 } \\
\text { M4 }\end{array}$ & $\begin{array}{l}\text {...com üzerinden alışveriş yapmaktan hoşlanıyorum. } \\
\text {...com üzerinden alışveriş yapmaktan memnunum. } \\
\text {...com üzerinden alışveriş yapmanın çok iyi bir fikir olduğunu düşünüyorum. } \\
\text { Genel olarak, ...com üzerinden alışveriş yapmak beni oldukça tatmin ediyor. }\end{array}$ \\
\hline Algilanan fayda [9] & $\begin{array}{l}\text { AF1 } \\
\text { AF2 } \\
\text { AF3 } \\
\text { AF4 } \\
\text { AF5 }\end{array}$ & $\begin{array}{l}\text {...com ile daha hızlı alışveriş yapıyorum. } \\
\text {...com firsat sitesini kullanarak alışverişte daha isabetli kararlar veriyorum. } \\
\text {...com firsat sitesi benim için alışverişi kolaylaştırdı. } \\
\text {...com firsat sitesinden aradığımı daha ucuza alıyorum. } \\
\text { Tam anlamıyla, ...com firsat sitesi bence faydalı bir firsat sitesidir. }{ }^{\text {a }}\end{array}$ \\
\hline $\begin{array}{l}\text { Algilanan kullanım } \\
\text { kolaylığı [32] }\end{array}$ & $\begin{array}{l}\text { AKK1 } \\
\text { AKK2 } \\
\text { AKK3 } \\
\text { AKK4 }\end{array}$ & $\begin{array}{l}\text {...com firsat sitesinin kullanmakta zorlanıyorum. }(\mathrm{R})^{\mathrm{a}} \\
\text {...com firsat sitesi içerisindeki yönergeler açık ve anlaşılır. } \\
\text {..com firsat sitesinin kullanımını kolay buluyorum. } \\
\text { Satın almak istediklerime ...com firsat sitesi üzerinden kolayca erişebiliyorum. }\end{array}$ \\
\hline Güven [20] & $\begin{array}{l}\text { G1 } \\
\text { G2 } \\
\text { G3 } \\
\text { G4 } \\
\text { G5 }\end{array}$ & $\begin{array}{l}\text { Geçmişteki deneyimlerimden, ...com'un dürüst olduğunu biliyorum. } \\
\text { Geçmişteki deneyimlerimden, ...com firsat sitesinin firsatçı olmadığını biliyorum. }{ }^{\text {a }} \\
\text { Geçmişteki deneyimlerimden, ...com firsat sitesinin verdiği sözü tutacağını biliyorum. } \\
\text { Geçmişteki deneyimlerimden, ...com'un güvenilir bir firsat sitesi olduğunu biliyorum. } \\
\text { Geçmişteki deneyimlerimden, ...com'un bekleneni fazlasıyla karşılayacağını biliyorum. }\end{array}$ \\
\hline $\begin{array}{l}\text { Algilanan saygınlık } \\
{[25]}\end{array}$ & $\begin{array}{l}\text { AS } 1 \\
\text { AS2 } \\
\text { AS3 } \\
\text { AS4 }\end{array}$ & $\begin{array}{l}\text {...com firsat sitesi iyi bilinen bir firsat sitesidir. }{ }^{\text {a }} \\
\text {...com firsat sitesi saygın bir firsat sitesidir. } \\
\ldots \text { com firsat sitesi güvenilir bir firsat sitesidir. } \\
\text {...com firsat sitesi müşterilerine değer veren bir firsat sitesidir. }\end{array}$ \\
\hline $\begin{array}{l}\text { Kişisel normlar } \\
\text { [33] }\end{array}$ & $\begin{array}{l}\text { SN1 } \\
\text { SN2 } \\
\text { SN3 } \\
\text { SN4 }\end{array}$ & $\begin{array}{l}\text { Görüşlerine değer verdiğim insanlar, ....com'u kullanıyor olmamı beğeniyorlar. }{ }^{\text {a }} \\
\text { Örnek aldığım insanlar, ...com'u kullanmam gerektiğini düşünüyorlar. } \\
\text { İnternet üzerinden alışverişte ....com'u kullanmam bekleniyor. } \\
\text { Önemsediğim insanlar, ...com'u kullanmam konusunda hemfikir. }\end{array}$ \\
\hline
\end{tabular}

R: Ters kodlama;

a: Sonraki analizlerden çıkarılan gözlenen değişkenler

\section{SONUÇLAR (RESULTS)}

Analiz için yapısal eşitlik modellemesinin iki aşamalı yaklaşımı- ölçüm modeli ve yapısal model kullanılmıştır. Analizi için LISREL 8.54 [35] yazılım programı kullanılmıştır.

\section{1. Ölçüm Modeli (Measurement Model)}

Araştırma modelinde yer alan örtük değişkenler ve bunları tanımlayan gözlenen değişkenler arasındaki ilişkiyi test etmek için Doğrulayıcı Faktör Analizi gerçekleştirilmiştir. Analiz sonuçlarına göre uyum iyiliği değerlerinin önerilen uyum iyiliği değerlerini sağlamadığı gözlemlenmiştir. Uyum iyiliği değerlerini iyileştirmek için ilk aşamada örtük değişkenlerle gözlenen değişkenler arasındaki $t$-değerlerinin anlamlılık düzeyleri incelenmiştir. Modelde tanımlı tüm örtük değişkenlerle gözlenen değişkenler arasındaki ilişki anlamlı çıkmıştır. İkinci aşamada standart faktör ağırlığı 0.50 'den küçük gözlenen değişkenler modelden çıkartılmıştır. Gözlenen değişkenin modelden çıkarılmasına karar verirken ilgili gözlenen değişkenin modelden çıkartıldığı takdirde örtük değişkenin açıklanması yani teorik olarak bir problem olmadığı durumda ilgili gözlenen değişken modelden çıkartılmıştır [36]. Sonuç olarak, ölçme modelinde yapılan değişiklikler sonucu güven, algılanan fayda, algılanan saygınlık, kişisel normlar ve algılanan kullanım kolaylığı örtük değişkenlerinden birer değişken (G2, AF5, SN1, AS1, AKK1) modelden ç1kartılarak ölçme modelindeki 7 örtük değişkeni tanımlayabilen 24 gözlenen değişkenin modelde kalmasına karar verilmiştir. Tablo 2'de bundan sonraki aşamalarda modelden çıkarılan gözlenen değişkenler işaretlenmiştir. Yapılan modifikasyonlar sonucunda, Tablo 3 'de gösterildiği üzere ölçme modelinin uyum iyiliği değerlerinin önerilen değerlerden daha iyi değerler verdiği bulunmuştur. Bu sonuç, ölçme modelinin toplanan veri ile uyum gösterdiğini gösterir.

Tablo 3. Ölçüm modeli uyum iyiliği istatistikleri

\begin{tabular}{lll}
\hline Uyum iyiliği istatistikleri & Sinır değer & Gerçek değer \\
\hline$\chi^{2} / \mathrm{df}(\chi 2 ; \mathrm{df})$ & $\leq 3$ & $2,18(504 ; 231)$ \\
RMSEA & $\leq 0,08$ & 0,07 \\
CFI & $\geq 0,90$ & 0,98 \\
NFI & $\geq 0,90$ & 0,98 \\
SRMR & $\leq 0,08$ & 0,05 \\
\hline
\end{tabular}

$\chi 2=$ ki-kare; $\mathrm{df}=$ serbestlik derecesi; RMSEA $=$ yaklaşık hataların ortalama karekökü; $\mathrm{CFI}=$ karşılaş̧ırmalı uyum indisi; $\mathrm{NFI}=$ normlanmış uyum indisi; SRMR= standart kök ortalama kare kalan 
Ölçüm modelinin güvenilirliği için uyuşum ve ayırt edici geçerliliklerinin sağlanması gerekir. Uyuşum geçerliliği, gözlenen değişkenlerin örtük değişkenleri ifade edip etmediğinin ölçümlenmesi olarak tanımlanabilir [37]. Uyuşum geçerliliğinin test edilmesinde standardize faktör ağırlıklarına, açıklanan ortalama değişkenlik ve yapı güvenilirliği değerleri incelenmiştir. Tablo 4'de gösterildiği üzere gözlenen değişkenlerin standardize faktör ağırlığı 0,70 'den büyük, ortalama açıklanan değişkenlik 0,5 'ten büyük, yapı güvenilirliği ve Cronbach's alfa değerleri 0,70'den büyük olduğundan ölçme modelinin uyuşum geçerliliğinin sağlandığı sonucuna varılabilir.

Tablo 4. Doğrulayıcı faktör analizi -uyuşum geçerliliği

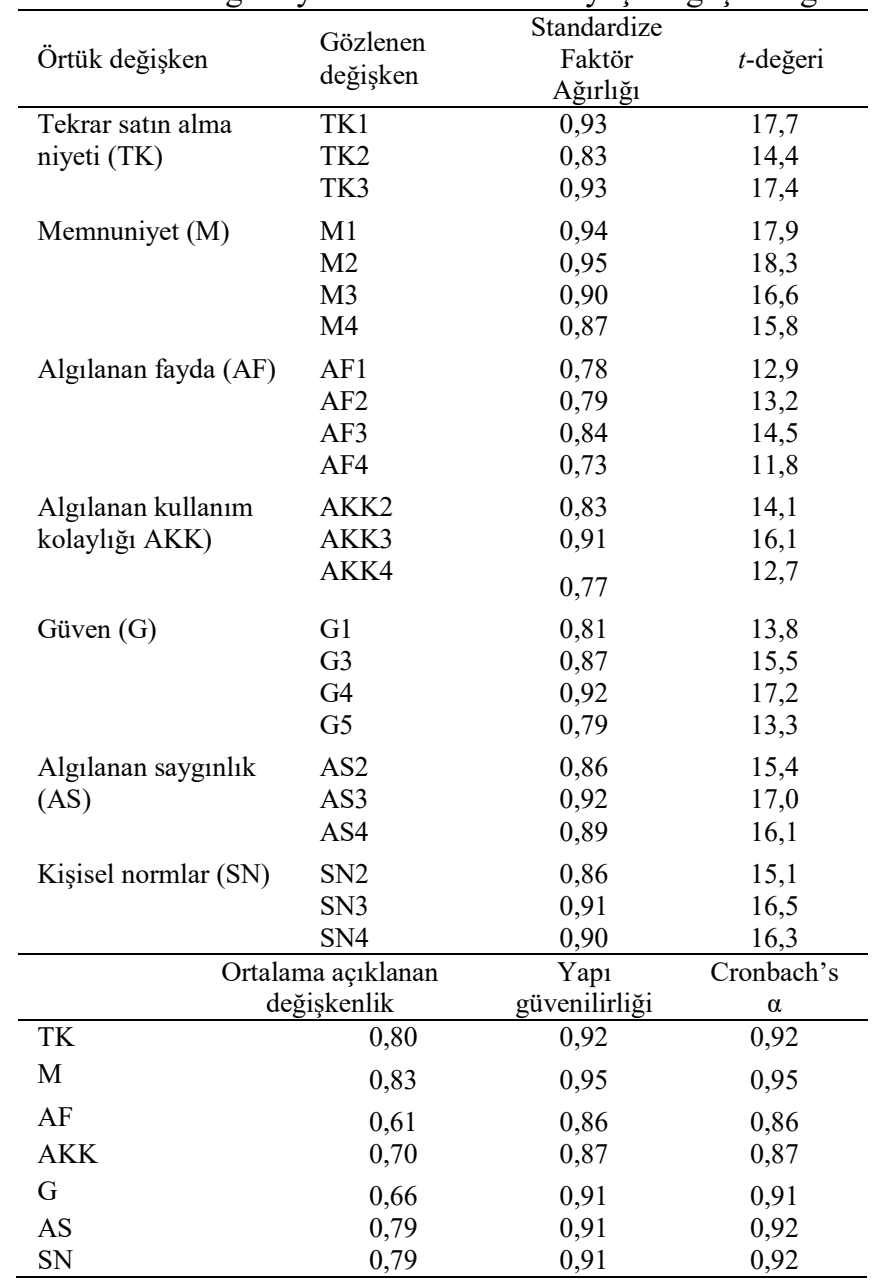

Ayırt edici geçerlilik, modelde var olan değişkenlerin birbirlerinden farklı değişkenler olup olmadığını ölçümlemede kullanılır. Ayırt edici geçerlilik için doğrulayıcı faktör analizi sonucu elde edilen ki-kare değeri (Kikare- $\chi 2=504)$ ile herhangi iki değişken arasındaki korelasyonun 1'e eşitlenmesi sonucu elde edilen ki-kare değeri arasındaki farkın anlamlılık düzeyine bakılmıştır ( $\Delta \mathrm{Ki}$ - kare $\chi 2=3,84$, serbestlik derecesi-df $=1, p=0,05)$. Tablo 5'te gösterildiği üzere bütün ki-kare fark değerleri 3,84 değerinden daha büyük olduğundan örtük değişkenler arasında istatistiksel bir fark olduğu söylenebilir.

Tablo 5. Ayırt edici geçerlilik.

\begin{tabular}{|c|c|c|c|c|c|c|c|}
\hline$\Delta \chi^{2}$ & TK & $\mathrm{M}$ & $\mathrm{AF}$ & AKK & $\mathrm{G}$ & AS & SN \\
\hline TK & & 68 & 107 & 146 & 136 & 142 & 345 \\
\hline $\mathrm{M}$ & & & 67 & 146 & 185 & 166 & 309 \\
\hline $\mathrm{AF}$ & & & & 144 & 133 & 135 & 179 \\
\hline AKK & & & & & 328 & 226 & 276 \\
\hline G & & & & & & 42 & 372 \\
\hline AS & & & & & & & 329 \\
\hline SN & & & & & & & \\
\hline
\end{tabular}

\subsection{Yapısal Model (Structural Model)}

Yapısal model, araştırma modelinde öne sürülen hipotezlerin geçerliliğinin test edilmesinde kullanılır. İlk aşamada, oluşturulan yapısal modelin uyum iyiliği değerleri incelenmiştir. Sonuçlara göre uyum iyiliği değerleri önerilen değerlerden daha iyi sonuçlar vermiştir $(\mathrm{RMSEA}=0,079 ; \mathrm{SRMR}=0,051 ; \mathrm{NFI}=0,97 ; \mathrm{CFI}=0,99)$. İkinci aşamada araştırma modelinde belirtilen örtük değişkenler arasındaki ilișkiler incelenmiştir. Şekil 2'de araştırma modelinde anlamlı ve anlamlı olmayan ilişkiler gösterilmiştir. Modelde belirtilen ilişkilerden kişisel normlar-tekrar satın alma niyeti arasındaki ilişki dışındaki tüm ilişkiler anlamlı bulunmuştur. Tekrar satın alma niyetini etkileyen en önemli faktör memnuniyet ve sonrasında da güvendir. Memnuniyet; güven, algılanan fayda ve algılanan kullanım kolaylığından etkilenmektedir. Algılanan saygınlığın, güven ve algılanan fayda üzerinde anlamlı ve pozitif bir etkisi vardır. Kişisel normların ise algılanan faydaya anlamlı bir etkisi olmasına karşın tekrar satın alma niyeti üzerindeki etkisi anlamlı çıkmamıştır. 


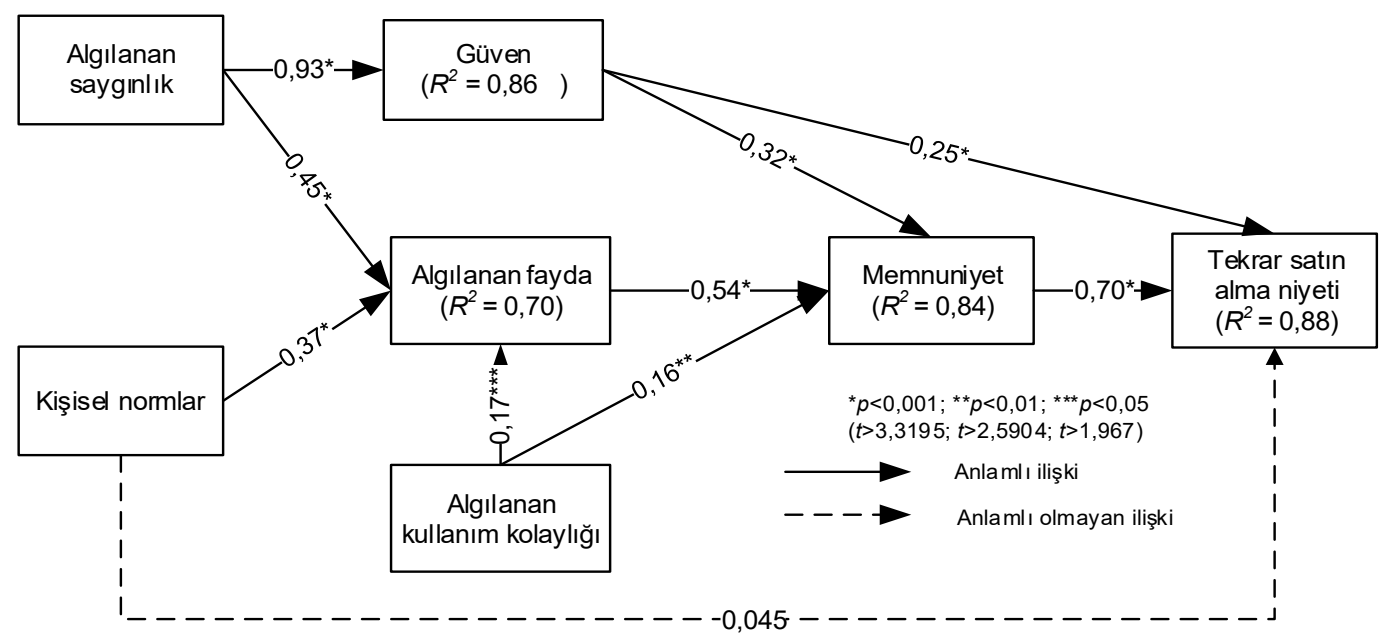

Şekil 2. Araştırma modeli sonuçları

\section{TARTIŞMA VE GELECEK ÇALIŞMALAR (DISCUSSION AND FUTURE STUDIES)}

Fırsat sitelerinin sayısının artması ve sitelerin birbirlerine benzer ürünler sunması müşterilerin bir firsat sitesinden diğerine kolaylıkla geçmesine neden olabilmektedir [8, 5] $\mathrm{Bu}$ yüzden firsat sitesinin başarılı olabilmesi için müşteri sadakati ve siteden tekrarlı ürün alışverişi önemlidir. Sonuçlar incelendiğinde firsat sitesine duyulan güven müşteri memnuniyetini ve firsat sitesini yeniden kullanım niyetini etkilemektedir. $\mathrm{Bu}$ sonuç literatürdeki çalışmalarla da örtüşmektedir [7, 21, 20]. Müşterinin, firsat siteleri ile ilgili ve ürünle ilgili deneyimleri güveni ve memnuniyeti etkilemektedir [7]. Bu yüzden firmalar, müşterilerinin firmaya duydukları güveni koruyacak/arttıracak veya zedelemeyecek faaliyetlerde bulunmalıdırlar. Özellikle firsat sitesinin sunduğu firsatlar, müşterilerin beklediği gibi gerçekleşmediğinde güvensizlik oluşabilir. Örneğin firsat sitesinden aldığınız bir akşam yemeği kuponunu kullandığınızda size sunulan menü ve hizmetler firsat sitesinin vaat ettiği gibi değilse müşteri firsat sitesini kullanmayı bırakabileceği gibi hizmeti sunan restorana tekrar gitmeyi düşünmeyebilir. $\mathrm{Bu}$ yüzden müşterilerin hem kupon temin sürecindeki memnuniyetleri hem de kuponu kullandıktan sonra aldıkları hizmetten memnuniyetlerini artıracak çalışmalar yapılmalıdır. Müşterilere yönelik olarak firmanın sunduğu ürün/hizmetin söz verildiği şekilde gerçekleşip gerçekleşmediğine yönelik algı anketi uygulanabilir. Elde edilen geri beslemeler doğrultusunda da firsat sitesi kendisini geliştirme yoluna gitmelidir.

Memnuniyeti etkileyen faktörler incelendiğinde algılanan fayda, güven ve algılanan kullanım kolaylığının etkileri anlamlıdır. Müssteriler ilk olarak sunulan ürün/hizmetin faydalı olmasını beklemekte, daha sonra sunulan hizmetin beklenildiği şekilde gerçekleşmesi ve en sonda da fursat sitesinden satın alma faaliyetini gerçekleştirirken işlemi zorlanmadan kolaylıkla yapmayı istemektedirler. Firmalar müşterilerin beklentilerini belirlemek üzere beklenti anketleri veya müşterilerden gelen mesajlar, geri beslemeler ve şikayetleri dikkate alarak sunacakları ürün/hizmete karar vermelidirler. Tüm potansiyel kullanıcıların aynı bilgisayar okuryazarlığı bulunmadığ düşünüldüğünde tüm müşterilerin rahatlıkla kullanabilecekleri kullanılabilirliği yüksek evrensel bir web sitesi tasarlanmalıdır. Bunun için müşterilerin karşılaşacakları potansiyel problemleri belirlemeye yönelik kullanıcı testleri yapılarak müşterilerin sistemi rahatlıkla kullanmaları sağlanabilir.

Firmalar saygınlıklarını arttırıcı faaliyetlerde bulunmalıdır ki bu sayede müşterilerin firmaya olan güvenleri artmaktadır. Sanal ortamlarda müşterilerin alacakları ürünü önceden incelemeleri mümkün değildir. Bu yüzden ürünü alırken ürünle ilgili edindikleri bilgi ve ilgili ürün/hizmeti sağlayan firmanın web sitesinde ürün bilgileri karar vermelerinde etkilidir [38]. Firmanın söz verdiği şekilde sunduğu hizmet ise firmaya olan güveni arttırır. Aslında bir müşterinin güveni zedelendiğinde ve bununla ilgili yorumları internet ortamında paylaştığında birçok müşteri ilgili hizmeti almaktan vazgeçebilir. Ürün/hizmetle ilgili olumlu yorumlar müşterinin güvenini arttırır ve müşteri ürün/hizmeti almaya daha çabuk karar verebilir [39]. Bu yüzden firmaların söz verdikleri ürün/hizmeti söz verdikleri şekilde sunmaları firma için çok önemlidir.

Kişisel normların, algılanan fayda üzerinde anlamlı bir etkisi olmasına karşın tekrar kullanım niyeti üzerinde herhangi bir etkisi yoktur. $\mathrm{Bu}$ sonuç gösteriyor ki müşteriler için kendileri için önemli kişilerin ürün/hizmetle ilgili telkinleri ürünün faydalı olduğu yönündeki algıyı etkilemekle birlikte tekrar kullanım niyeti üzerinde anlamlı bir etkisi çıkmamıştır. Müşteriler memnun kaldıkları ve güven duydukları siteden tekrar satın alma yapmayı düşünürler. Benzer şekilde Zhang ve diğ. [6] yaptıkları çalışmada sosyal baskının fırsat sitesini tekrar kullanım niyeti üzerindeki etkilerini araştırmışlardır. Sonuçlar incelendiğinde sosyal baskı faktörlerinden algılanan kritik ağırlık faktörünün anlamlı bir etkisi varken kişisel normların anlamlı bir etkisi bulunmamıştır. Çalışmalarında sosyal baskının temel olarak üç aşaması olduğunu vurgulamışlardır: Uyma, 
Proceedings of the 21st Americans Conference on Information Systems, August 13-15, Puerto Rico, 2015.

[9] C. Wen, V.R. Prybutok, C. Xu, "An integrated model for customer repurchase intention", Journal of Computer Information Systems, 52(1), 14-23, 2011.

[10] J.Y.L. Thong, S. Hong, and K.Y. Tam, "The effects of post adoption beliefs on the expectation-confirmation model for information technology continuance", International Journal of Human-Computer Studies, 64, 799-810, 2006.

[11] A. Bhattacherjee, "Understanding information systems continuance: An expectation-confirmation model. MIS Quarterly, 25(3), 351-370, 2001.

[12] C. Liu, Y.M. Guo, and C. Lee, "The effects of relationship quality and switching barriers on customer loyalty", International Journal of Information Management, 31, 71-79, 2011.

[13] Y. Chen, H. Huang, H., Y. Hsu, H. Tseng, Y. Lee, “Confirmation of expectations and satisfaction with the internet shopping: The role of internet self-efficacy", Computer and Information Science, 3(3), 14-22, 2010 .

[14] T.J. Larsen, A.M. Sorebo, and O. Sorebo, "The role of tasktechnology fit as users' motivation to continue information system use", Computers in Human Behavior, 25, 778-784, 2009.

[15] W. Lin, "Perceived fit and satisfaction on web learning performance: IS continuance intention and task-technology fit perspectives", International Journal of Human-Computer Studies, 70, 498-507, 2012.

[16] T. Zhou, "An empirical examination of continuance intention of mobile payment services", Decision Support Systems, 54, 1085-1091, 2013.

[17] R.C. Mayer, J.H. Davis, and F.D. Schoorman, "An integrative model of organizational trust", The Academy Management Review, 20(3), 709-734, 1995

[18] D.H. McKnight, V. Choudhury,. and C. Kacmar, "Developing and validating trust measures for e-commerce: An integrative typology', Information Systems Research, 13(3), 334-359, 2002.

[19] P. Moradi, and S. Ahmadian, "A reliability-based recommendation method to improve trust-aware recommender systems", Expert Systems with Applications, 42, 7386-7398, 2015.

[20] H.H. Lin, and Y.S. Wang, "An examination of the determinants of customer loyalty in mobile commerce contexts", Information \& Management, 43, 271-282, 2006.

[21] J. Kim, B. Jin, and J.1. Swinney, "The role of etail quality, esatisfaction and e-trust in online loyalty development process", Journal of Retailing and Consumer Services, 16, 239-247, 2009.

[22] F.D. Davis, "Perceived usefulness, perceived ease of use, and user acceptance of information technology", MIS Quarterly, 13(3), 319-339, 1989.

[23] F.D. Davis, R.P. Bagozzi, and P.R. Warshaw, "User acceptance of computer technology. A comparison of two theoretical models. Management Science, 35(8), 982-1003, 1989.

[24] E.S. Wang, N.P. Chou, "Consumer characteristics, social influence, and system factors on online group-buying repurchasing intention", Journal of Electronic Commerce Research, 15(2), 119-132, 2014.

[25] M. Koufaris, and W. Hampton-Sosa, "The development of initial trust in an online company by new customers", Information \& Management, 41, 377-397, 2004.
[7] W. Shiau, and M.M Luo, "Factors affecting online group buying intention and satisfaction: A social exchange theory perspective", Computers in Human Behavior, 928, 2431-2444, 2012.

[8] L. Huang, L. Jia, and J. Song, "Antecedents of user stickiness and loyalty and their effects on users' group buying repurchase intention", 
[26] M.N. Akroush, and M.M. Al-Debei, "An integrated model of factors affecting consumer attitudes towards online shopping", Business Process Management Journal, 21(6), 1353-1376, 2015.

[27] I. Ajzen, and M. Fishbein, Understanding attitudes and predicting social behavior. Prentice-Hall, Upper Saddle River, NJ, 1980.

[28] V. Venkatesh, and F.D. Davis, "A theoretical extension of the technology acceptance model: Four longitudinal Field Studies", Management Science, 46(2), 186-208, 2000.

[29] S.C. Chen, D.C. Yen, and M.I. Hwang, "Factors influencing the continuance intention to the usage of Web 2.0: An empirical study", Computers in Human Behavior, 28(3), 933-941, 2012.

[30] C.W.D. Chen and C.Y.J. Cheng, "Understanding consumer intention in online shopping: A respecification and validation of the DeLone and McLean model". Behaviour \& Information Technology, 28(4), 335-345, 2009

[31] Y.H. Fang, C.M. Chiu, and E.T. Wang, "Understanding customers' satisfaction and repurchase intentions", Internet Research, 21(4), 479503, 2011.

[32] X. Tong, "A cross-national investigation of an extended technology acceptance model in the online shopping context", International Journal of Retail \& Distribution Management, 38(10), 742-759,2010.

[33] I.R.D. Bosque, and A.H. Crespo, "How do internet surfers become online buyers? An integrative model of e-commerce acceptance", Behaviour \& Information Technology, 30(2), 161-180, 2011.

[34] J.F. Hair, R.E. Anderson, R.L. Tatham, and W.C. Black, Multivariate Data Analysis, Prentice Hall, Upper Saddle River, NJ, 1998
[35] K. Jöreskog, and D. Sörbom, LISREL 8.54. Scientific Software International, 2003.

[36] J.C. Anderson, and D.W. Gerbing, "Structural equation modeling in practice: A review and recommended two-step approach", Psychological Bulletin, 103(3), 411-423, 1988

[37] R.P. Bagozzi, and L.W. Philips, L.W., Representing and testing organizational theories. A holistic construal", Administrative Science Quarterly, 27(3), 459-489, 1982.

[38] M.T. Liu, J.L. Brock, G.C. Shi, R. Chu, and T. Tseng, "Perceived benefits, perceived risk, and trust Influences on consumers' group buying behavior", Asia Pacific Journal of Marketing and Logistics, 25(2), 225-248, 2013

[39] R.J. Kauffman, H. Lai, and C. Ho, "Incentive mechanisms, fairness and participation in online group-buying auctions", Electronic Commerce Research and Applications, 9, 249-262, 2010.

[40] H.C. Kelman, "Compliance, identification, and internalization: three processes of attitude change", The Journal of Conflict Resolution, 2(1),51-60, 1958.

[41] W. Wang, Y. Wang, and E. Liu, "The stickiness intention of groupbuying websites: the integration of the commitment-trust theory and ecommerce success model", Information \& Management, 53(5), 625-642, 2016 . 